\title{
Protein status of holshtinized black and white cattle
}

\author{
O.I. Sebezhko, R.V. Mayer, E.I. Tarasenko*, V.G. Marenkov, and V.V. Garth
}

Novosibirsk State Agrarian University, Novosibirsk, Russia

\begin{abstract}
We studied protein metabolism in Holsteinized black-and-white cattle. The researches were conducted in the Kuzbass at OJC «Vaganovo». Blood sample was taken from each cow, according to generally accepted of methods and analyzed in the laboratory of biochemistry from Novosibirsk State Agrarian University by using standard kits of biochemical studies on a biochemical semiautomatic analyzer Photometer 5010 V5 +. The indicators of protein metabolism were established in the blood serum of Holsteinized black-and-white cattle in average values; creatinine was characterized by the lowest phenotypic variability. The greatest positive relationship was found between albumin/globulin coefficients and albumin $(\mathrm{r}=0.765)$. The reference intervals were calculated for cows of the 3rd lactation of the Holsteinized black-and-white breed with a high level of milk productivity $(9-10$ thousand $\mathrm{kg}$ ): total protein $62.02-87.58 \mathrm{~g} / \mathrm{l}$; albumin 21.05-36.09 g / 1; urea 2.2-4 mmol / 1; creatinine 50-71 $\mu \mathrm{mol} / \mathrm{l}$; albumin-globulin coefficients $0.35-1.16$. The data obtained can be used for assess the interior of animals.
\end{abstract}

\section{Introduction}

At the moment, cattle breeding from Kuzbass is a dynamically developing industry in animal husbandry.

The requirements dictated from conditions in modern market of raising cattle to obtain high-quality and safe products at minimal cost. To increase the efficiency in production of ecologically safe livestock products, it is necessary to make analisis if monitor water, soil, plants sampels for the content of macro- and microelements in water, soil, feed, organs and animals tissues $[1,7,14]$.

Important reserve of increasing the production of products and reducing its cost are balanced feeding of animals with the help of which it is possible to increase the productivity of animals by at least $20 \%$. Digestible protein are take particular attention of providing diets. Protein deficiency negatively affects of physiological state of the animal, protein metabolism and it is a reason of productivity decreases [8, 13, 27]. In addition, the prevailing global deficit of protein and energy in rations leads to a large overspending of feed.

Proteins and amino acids are the main building blocks for muscles in animal rearing, playing an important role in metabolic and energy processes. They provide growth,

*Corresponding author: tarasenkoo1997@mail.ru 
development, reproduction qualities, productivity. Therefore, in order to deepen control over the completeness of feeding cows and prompt response to nutritional imbalances and adjustments in rations, it is necessary to assess the state of protein metabolism $[6,9,15]$.

Studies on the protein status of cattle make it possible to describe the mechanisms of interaction between the genetic and environmental regulation functioning in animal organism.Many attempts have been made to better understand the unique protein metabolism of ruminants to improve productivity, feed and growth efficiency, and disease resistance [28].

In addition, the milk productivity of animals is determined and inextricably linked with the intensive course of protein metabolism in the body systems, as well as the physiologically intense period of ontogenesis - lactation.Based on this, the goal was set to conduct biochemical monitoring in Holsteinized black-and-white cattle [22-23].

2 Materials and methods

Biochemical status was investigated of 40 Holsteinized cows of OJC «Vaganovo». Blood was collected using the vakuet method from the tail vein of animals in the morning before feeding.

Studies were carried out in a sample of 3rd lactation cows of Holsteinized black-and-white cattle from Kuzbass. Feeding ration corresponded by zootechnical standards for a given milk production (9-10 thousand $\mathrm{kg}$ ). The animals were clinically healthy at the time of sampling.

In blood serum were determined according to unified methods following parameters: total protein, albumin, urea, creatinine, and also calculated globulin and albumin-globulin coefficient (AGC). These indicators most accurately reflect protein metabolism.

Blood serum parameters were determined using a biochemical semi-automatic analyzer Photometer 5010V5+ (ROBERTRIELEGmbH\&CoKG,Germany).Photometer 5010V5+ semi-automatic analyzer designed to perform a wide range of analysis for clinical biochemistry.

In the area of animal breeding, monitoring of soil, water and feed was carried out for the content of heavy metals, the level of which did not exceed the MPC [16, 17-18, 20].

Statistical processing of experimental data was carried out by using standard methods of descriptive statistics.The Anderson-Darling statistic was used to test normality of distribution.Pearson coefficient was used to determine correlation ratios with error and reliability.

By the Fligner-Killeen method was carried out evaluation of the homoscedasticity dispersions of the content biochemical parameters in the blood serum on the studied animals. This method can be used to check the homogeneity or heterogeneity of dispersions $[5,21,10-11]$.

The Kruskal-Wallis test was used for determining intergroup differences as an alternative non parametric analogue of one-way ANOVA when comparing 3 or more independent groups [4, 19, 24].

Reference intervals were determined by the robust statistical methods. Confidence intervals for the reference limits were calculated by using bias-corrected and accelerated percentile interval method, that corrects possible bias and skewness in the original distribution $[2-3,25,26]$.

Statistical processing of data was carried out by using the Microsoft Office Excel 2007 program, the statistical programming language and the RStudio data analysis environment, version 1.2.5033. 


\section{Results and discussion}

Milkproductivityofanimalsisdeterminedandinextricablylinkedwiththeintensivecourseofprote inmetabolisminthebodysystems, aswellasthephysiologicallyintenseperiodofontogenesislactationThus, goal was set to conduct biochemical monitoring of animals, assess variability and establish reference intervals of biochemical parameters for Holsteinized black-andwhite cattle in the ecological and climatic conditions from Kuzbass during the 3rd lactation period.Results are presented of testing for the normal distribution of biochemical parameters in Table 1.

Table 1. Results of testing for the normal distribution of biochemical parameters (Anderson-Darling criterion)

\begin{tabular}{|l|c|c|}
\hline \multicolumn{1}{|c|}{ Index } & Criterion value & p-value \\
\hline Total protein, $\mathrm{g} / \mathrm{l}$ & 2,49 & 1,9 \\
\hline Albumin, $\mathrm{g} / \mathrm{l}$ & 0,79 & 0,03 \\
\hline Urea, $\mathrm{mmol} / \mathrm{l}$ & 1,07 & 0,007 \\
\hline Creatinine, $\mu \mathrm{mol} / \mathrm{l}$ & 0,7 & 0,05 \\
\hline Albumin-globulin coefficient & 1,66 & 0,0002 \\
\hline
\end{tabular}

The content of albumin, urea, creatinine and AGC was characterized by a normal Gaussian distribution, the total protein has a distribution different from normal $(\mathrm{p}>0,05)$.

Table 2. The content of biochemical parameters in the blood serum Holsteinized cattle of black-and-white breed from Kuzbass.

\begin{tabular}{|c|c|c|c|c|c|c|c|c|c|c|c|}
\hline $\begin{array}{c}\text { Inde } \\
\mathrm{x}\end{array}$ & $\bar{X} \pm \mathrm{S}_{\mathrm{x}}$ & $\mathrm{Me}$ & $\mathrm{Min}$ & $\mathrm{Max}$ & $\mathrm{Q}_{1}$ & $\mathrm{Q}_{3}$ & $\mathrm{IQR}$ & $\mathrm{Lim}$ & $\begin{array}{c}\text { Cv, } \\
\%\end{array}$ & $\begin{array}{c}\text { Attitude } \\
\text { extreme } \\
\text { option }\end{array}$ & Normal \\
\hline $\begin{array}{c}\text { Total } \\
\text { prote } \\
\text { in }\end{array}$ & $77,8 \pm 1,25$ & 80,6 & 62 & 87,6 & 70,4 & 84,1 & 13,7 & $\begin{array}{c}62- \\
87,6\end{array}$ & 10,2 & $1: 1,4$ & $\begin{array}{c}61,6- \\
82,2\end{array}$ \\
\hline $\begin{array}{l}\text { Albu } \\
\text { men }\end{array}$ & $29,2 \pm 0,67$ & 29,6 & 21 & 36,1 & 25,1 & 32,9 & 7,83 & $\begin{array}{c}21- \\
36,1\end{array}$ & 14,5 & $1: 1,7$ & $\begin{array}{c}27,5- \\
39,4\end{array}$ \\
\hline AGC & $0,63 \pm 0,03$ & 0,58 & 0,35 & 1,16 & 0,47 & 0,68 & 0,21 & $\begin{array}{c}0,356- \\
1,167\end{array}$ & 30 & $1: 3,31$ & $1,5-3$ \\
\hline Urea & $2,86 \pm 0,07$ & 2,83 & 2,2 & 4 & 2,54 & 3,1 & 0,558 & $2,2-4$ & 15,8 & $1: 1,81$ & $2,8-8,8$ \\
\hline $\begin{array}{l}\text { Creat } \\
\text { inine }\end{array}$ & $58,8 \pm 1$ & 57,5 & 50 & 71 & 53,4 & 62,7 & 9,27 & $50-71$ & 10,7 & $1: 1,4$ & $\begin{array}{c}55,8- \\
162,4\end{array}$ \\
\hline
\end{tabular}

The content of albumin in blood serum is below normal in $15 \%$ of animals. The remaining $25 \%$ of animals are within the normal range $(27,5-39,4 \mathrm{~g} / 1)$.

Average ratio in serum of albumin and globulins is 0,63 . In addition, the average values for the amount of total protein, albumin, urea, creatinine fall within the generally accepted normal values, with the exception of the albumin-globulin coefficient, which was significantly lower than normal (1,5-3).Blood urea accurately reflects rumen ammonia concentration and dietary protein level and quality. In $18 \%$ of animals, the urea content is below normal $(2,8-8,8 \mathrm{mmol} / \mathrm{l})$. It was noted that a lower standard error is observed precisely in urea than in other indicators and indicates that the data are grouped close to the mean.

Creatinine level in $28 \%$ of cows corresponds of physiological norm, but in other animals this indicator is below the norm, with content in the range of 55,8-162,4 $\mu \mathrm{mol} / 1$.

A high content of total protein was noted in $15 \%$ of the examined animals. Almost half $(25 \%)$ of the animals have within the normal range $(61,6-82,2 \mathrm{~g} / 1)$. A low content of total protein in blood serum was not revealed, which indicates the balanced feeding.Increase of protein content in serum is above normal may be consequence of increase in gammaglobulinimmune proteins, that indicating about metabolic tension. Increased protein level also indicates as highly concentrated type of feeding. 
Thus, established average values of nitrogen metabolism indices in the blood serum of Holsteinized black-and-white cattle with was in physiological norm. Coefficient of variation for all indicators was less than $33 \%$, which indicates the relative homogeneity of samples.

Figure 1 shows the degree of dispersion of biochemical parameters outside the 1 st and 3rd quartiles. Emissions are observed only for urea and AGC. The diagram shows: median, 1 st and 3rd quartiles, upper and lower bounds. In addition, symmetrical data are observed in the plots for albumin, urea, creatinine, and AGC. A slight shift in indicators is observed for total protein and AGC.

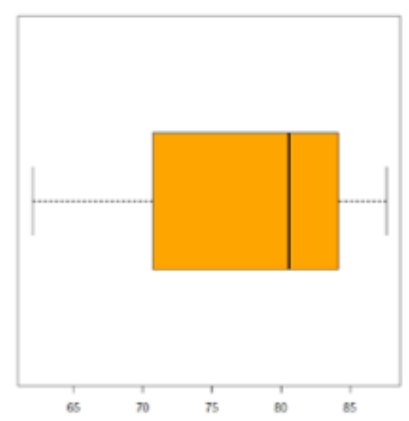

Total protein

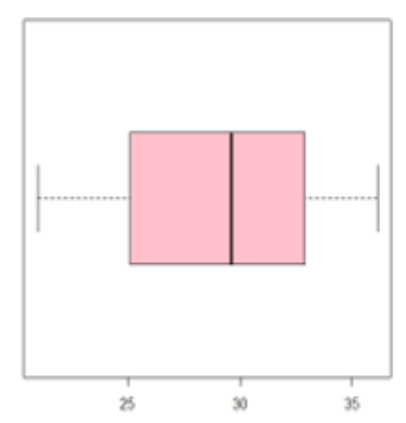

Albumin

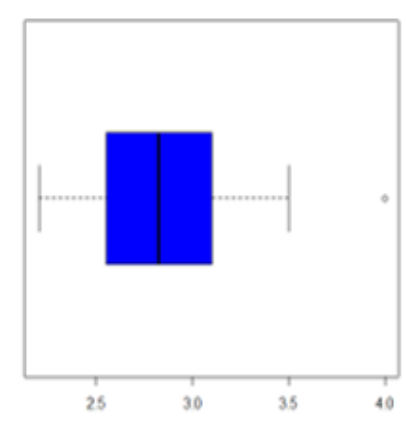

Urea

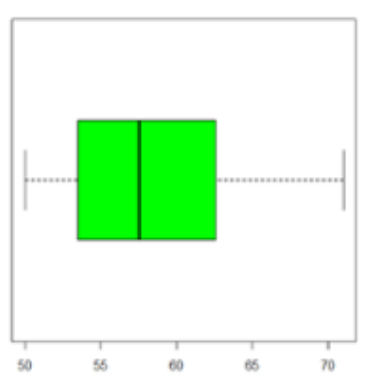

Creatinine

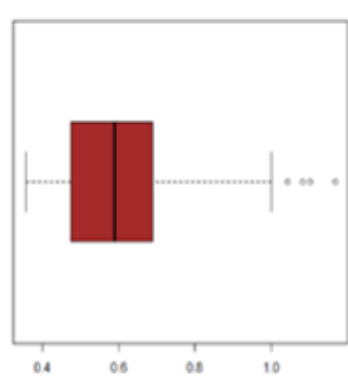

AGC

Fig. 1. Diagram of range in the content of biochemical parameters in the blood serum of Holsteinized black-and-white cattle.

Table 3. Results of testing the homogeneity of dispersion between biochemical parameters (Fligner-Killeen test).

\begin{tabular}{|c|c|c|c|c|}
\hline \multicolumn{2}{|c|}{ Factor } & Fligner-Killeen test & p-value & df \\
\hline \multirow{3}{*}{ Total protein } & Albumen & 22,39 & 0,61 & 25 \\
\cline { 2 - 5 } & Urea & 14,41 & 0,41 & 14 \\
\cline { 2 - 5 } & Creatinine & 36,43 & 0,16 & 29 \\
\hline \multirow{2}{*}{ Albumen } & Urea & 15,74 & 0,32 & 14 \\
\cline { 2 - 5 } & Creatinine & 34,42 & 0,22 & 29 \\
\hline Urea & Creatinine & 37,94 & 0,12 & 29 \\
\hline
\end{tabular}

$* \mathrm{df}$ - the number of degrees freedom

Testing for homogeneity of dispersions between biochemical parameters was performed using the Fligner-Keelin test. During the study, was found that the Fligner-Kilin test does 
not give a significant result, therefore, the medium is homogeneous ( $\mathrm{p}>0.05)$ (Table 3 ). Subsequently, correlation analysis was performed using by Pearson's method.

Table 4. Correlation between some biochemical parameters according to Pearson's method.

\begin{tabular}{|c|c|c|}
\hline \multicolumn{2}{|c|}{ Correlating factors } & $\mathrm{r} \pm \mathrm{S}_{\mathrm{r}(\mathrm{n})}$ \\
\cline { 2 - 3 } Total protein & Albumen & $-0.048 \pm 0.162(40)$ \\
\cline { 2 - 3 } & Urea & $0.089 \pm 0.162(40)$ \\
\cline { 2 - 3 } & Creatinine & $-0.248 \pm 0.157(40)$ \\
\cline { 2 - 3 } & AGK & $-0.648 \pm 0.124 * * *(40)$ \\
\hline \multirow{2}{*}{ Albumen } & Urea & $0.089 \pm 0.162(40)$ \\
\cline { 2 - 3 } & Creatinine & $0.094 \pm 0.162(40)$ \\
\cline { 2 - 3 } & AGK & $0.765 \pm 0.104 * * *(40)$ \\
\hline \multirow{2}{*}{ Urea } & Creatinine & $0.494 \pm 0.141 * *(40)$ \\
\cline { 2 - 3 } & AGK & $0.157 \pm 0.160(40)$ \\
\hline Creatinine & AGK & \\
\hline
\end{tabular}

$* \mathrm{P}<0,05 ; * * \mathrm{P}<0,01 ; * * * \mathrm{P}<0,001$

Correlation analysis according to Pearson's method showed that there is positive relationship between some biochemical parameters. The highest positive relationship was found between AGC and albumin $(r=0,765)$ (Table 4). Negative relationship was found between total protein and AGC $(r=-0,648)$.

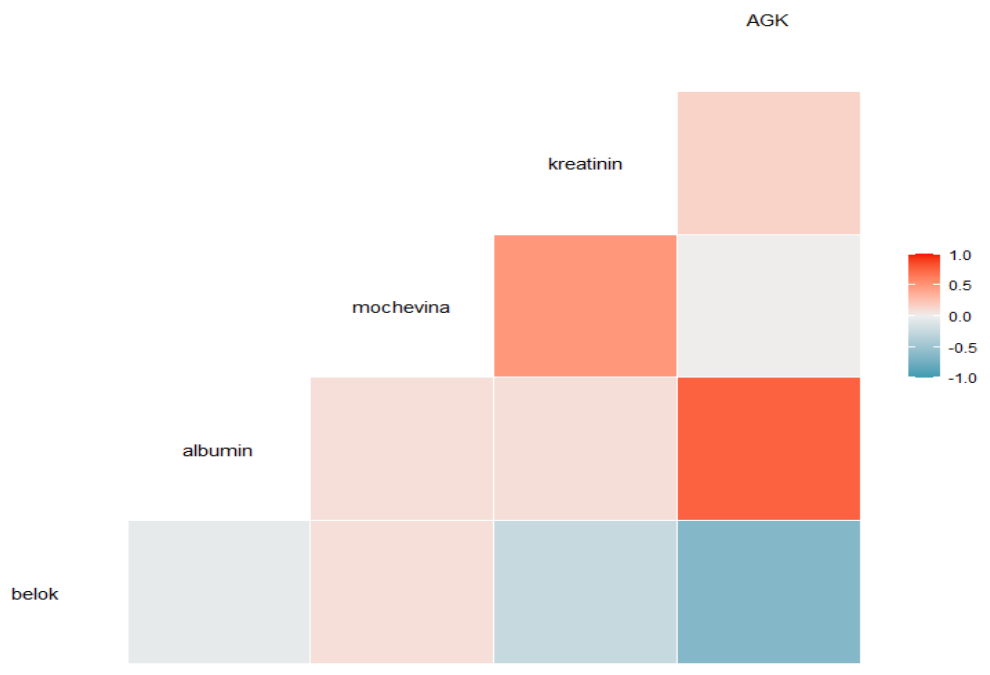

Fig. 2. Heat map.

Correlation analysis confirms this legend of the graph (Fig. 2), which shows the color of the gradient from -1 to 1 , hot color indicates strong positive correlation, and cold color indicates negative correlation.

Figure 2 shows a positive positive correlation between albumin-AGC and ureacreatinine.

Data about reference intervals of biochemical parameters in the blood serum of Holsteinized black-and-white cattle are presented in Table 5. 
After obtained reference values, typical for normal course of metabolic processes in the body of dairy cows, the norm for these environmental and climatic conditions, including anthropogenic load in Kuzbass conditions, will be clear.

Table 5. Reference intervals with $90 \%$ confidence intervals (CI) for the content of biochemical parameters in the blood serum of black-and-white Holstein cattle.

\begin{tabular}{|l|c|c|c|}
\hline \multicolumn{1}{|c|}{ Factor } & $\begin{array}{c}\text { Reference } \\
\text { intervals }\end{array}$ & $\begin{array}{c}\text { Lower limit of } 90 \% \\
\text { CI }\end{array}$ & $\begin{array}{c}\text { Upper limit of } \\
90 \% \text { CI }\end{array}$ \\
\hline Total protein, g/ & $62,02-87,58$ & $62-62,05$ & $86,19-87,6$ \\
\hline Albumin, g/ 1 & $21,05-36,09$ & $21-21,075$ & $35-36,1$ \\
\hline Urea, $\mathrm{mmol} / 1$ & $2,2-4$ & $2,200-2,2025$ & $3,14-4$ \\
\hline Creatinine, $\mu \mathrm{mol} / 1$ & $50-71$ & $50-50,02$ & $69,9-71$ \\
\hline $\begin{array}{l}\text { Albumin Globulin } \\
\text { Ratio }\end{array}$ & $0,35-1,16$ & $0,356-0,357$ & $1,08-1,16$ \\
\hline
\end{tabular}

Calculated reference intervals of blood biochemical parameters, the values are correspond to normal, optimal course of protein metabolism in the body of dairy cows (Fig. 3). The obtained values will allow for biocorrection functional state of the organs in highly productive dairy cows.

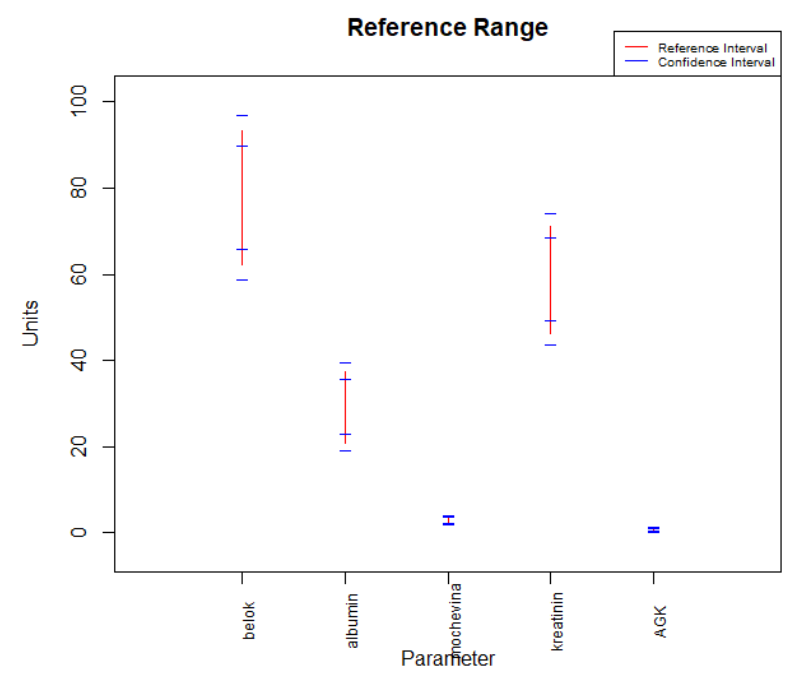

Fig. 3. Confidence intervals of biochemical parameters in the blood serum of Holsteinized black-andwhite cattle.

\section{Conclusions}

1. The average values were determined indicators of protein metabolism in the blood serum of Holsteinized black-and-white cattle, which were within the physiological norm.

2. Creatinine was characterized by the lowest phenotypic variability. According to the level of variability, the indicators of protein metabolism were arranged in the form of decreasing sequence: AGC - urea - albumin - total protein - creatinine.

3. Revealed positive correlations between some biochemical parameters, which reflects the physiological course of protein metabolism. The greatest positive relationship was found between AGC and albumin $(r=0,765)$. 
4. Reference intervals have been determined for cows of the 3rd lactation of the Holsteinized black-and-white breed with high level of productivity: total protein $62,02-$ 87,58 g / 1; albumin 21,05-36,09 g / 1; urea 2,2-4 mmol / 1; creatinine 50-71 $\mu \mathrm{mol} / \mathrm{l}$; AGK $0,35-1,16$. These values allow monitoring the functional state of the body of highly productive dairy cows.

\section{References}

1. O.S. Korotkevich, V.L. Petukhov, O.I. Sebezhko, Ye.Ya. Barinov, T.V. Konovalova, Russian Agricultural Sciences 40 (3), 195-197 (2014)

2. O.S. Korotkevich, M.P. Lyukhanov, V.L. Petukhov, N.S. Yudin, T.V. Konovalova, O.I. Sebezhko, E.V. Kamaldinov, Proceeding of the 10th World Congress on Genetics Applied to livestock Production (2014)

3. K.N. Narozhnykh, T.V. Konovalova, V.L. Petukhov, A.I. Syso, O.I. Sebezhko, N.I. Shishin, J.I. Fedayev, O.S. Korotkevich, E.V. Kamaldinov, L.V. Osadchuk, International Journal of Advanced Biotechnology and Research 7 (4), 1758-1764 (2016)

4. K.N. Narozhnykh, T.V. Konovalova, J.I. Fedyaev, N. Shishin, A. Syso, O.I. Sebezhko, V.L. Petukhov, O.S. Korotkevich, E.V. Kamaldinov, L.V. Osadchuk, Indian Journal of Ecology, 44 (2), 217-220 (2017)

5. K.N. Narozhnykh, O.I. Sebezhko, T.V. Konovalova, O.S. Korotkevich, V.L. Petukhov, E.I. Tarasenko, Trace Elements and Electrolytes 38 (3), 149 (2021)

6. L.V.Osadchuk, M.A. Kleshchev, O.I. Sebezhko, O.S. Korotkevich, N.I. Shishin, T.V. Konovalova, K.N. Narozhnykh, V.L. Petukhov, Iraqi Journal of Veterinary Sciences 31 (1), 35-42 (2017)

7. V.L. Petukhov, A.I. Syso, K.N. Narozhnykh, T.V. Konovalova, O.S. Korotkevich, O.I. Sebezhko, E.V. Kamaldinov, L.V.Osadchuk, Research Journal of Pharmaceutical, Biological and Chemical Sciences, 7 (4), 2458-2464 (2016)

8. V.L. Petukhov, I.A. Afonina, O.I. Sebezhko, O.S. Korotkevich, T.V. Konovalova, K.N. Narozhnykh, A.G. Nezavitin, I.I. Klimenok, A.V. Nazarenko, E.A. Klimanova, M.A. Kleshev, L.V. Osadchuk, N.M. Kostomakhin, D.S. Adushinov, G.M. Goncharenko, Indian Journal of Ecology 46 (4), 901-906 (2019)

9. O.I.Sebezhko, O.S. Korotkevich, T.V. Konovalova, I.S. Biryula, V.L. Petukhov, E.V. Kamaldinov, K.N. Narozhnykh, A.G. Nezavitin, V.N. Dementev, A.V. Nazarenko, L.V. Osadchuk, Journal of Agricultural, Food, and Environmental Sciences 71 (1), 186-190 (2017)

10. O.I.Sebezhko, V.L. Petukhov, O.S. Korotkevich, T.V. Konovalova, E.V. Kamaldinov, A.I. Syso, N.I. Marmuleva, K.N. Narozhnykh, E.Y. Barinov, L.V. Osadchuk, V.A. Sokolov, Indian Journal of Ecology 44 (3), 662-666 (2017)

11. O.I. Sebezhko, V.L. Petukhov, N.I. Shishin, O.S. Korotkevich, T.V. Konovalova, K.N. Narozhnykh, A.I. Zheltikov, V.G. Marenkov, A.G. Nezavitin, L.V. Osadchuk, R.B. Chysyma, E.E. Kuzmina, Journal of Pharmaceutical Sciences and Research 9 (9), 1530-1535 (2017)

12. T.V.Skiba, A.R. Tsygankova, N.S. Borisova, K.N. Narozhnykh, T.V. Konovalova, O.I. Sebezhko, O.S. Korotkevich, V.L. Petukhov, L.V. Osadchuk, Journal of Pharmaceutical Sciences and Research, 9 (6) 958-964 (2017) 
13. A.I. Syso, M.A. Lebedeva, A.S. Cherevko, V.L. Petukhov, O.I. Sebezhko, T.V. Konovalova, O.S. Korotkevich, K.N. Narozhnykh, E.V. Kamaldinov, V.A. Sokolov, Journal of Pharmaceutical Sciences and Research 9 (4), 368-374 (2017)

14. A.R.Tsygankova, A.V. Kuptsov, A.I. Saprykin, K.N. Narozhnykh, T.V. Konovalova, O.I. Sebezhko, O.S. Korotkevich, V.L. Petukhov, L.V. Osadchuk, Journal of Pharmaceutical Sciences and Research 9 (5), 601-605 (2017)

15. M.P. Lyukhanov, V.L. Petukhov, O.S. Korotkevich, O. I. Sebezhko, Animal husbandry 3, 2-3 (2015)

16. M.P. Lyukhanov, O.S. Korotkevich, V.L. Petukhov, O. I. Sebezhko, Chief zootechnician 10, 21-26 (2014)

17. E.P. Mazurina, O. I. Sebezhko, N.I. Shishin, A.V. Nazarenko, E.V. Fikhman, Theory and practice of modern agricultural science. collection of the national (All-Russian) scientific conference, 115-117 (Novosibirsk State Agrarian University, 2018)

18. A.V. Nazarenko, O. I. Sebezhko, V.A. Andreeva, T.V. Konovalova, O.S. Korotkevich, M.A. Romanenko, E.A. Klimanova, R.T. Saurbaeva, K.N. Narozhnykh, V.L. Petukhov, N.N. Kochnev, Bulletinof NSAU (Novosibirsk State Agrarian University) 4 (53), 55-64 (2019)

19. A.V. Nazarenko, E.P. Mazurina, E.V. Fikhman, O. I. Sebezhko, Actual problems of the agro-industrial complex. collection of works of the scientific-practical conference of teachers, students, undergraduates and graduate students, dedicated to the 80th anniversary of the Novosibirsk State Agrarian University, 209-211 (Novosibirsk State Agrarian University, 2016)

20. K.N. Narozhnykh, Collection of scientific papers of the All-Russian Scientific Research Institute of Sheep and Goat Breeding, 1 (8), 466-468 (2015)

21. K.N. Narozhnykh, Influence of ecological and geographical conditions on the concentration of manganese and iron in the spleen of Hereford cattle in the conditions of some districts of the Novosibirsk region and Altai Territory, The role of agricultural science in sustainable development of rural areas. Collection of the V All-Russian (national) scientific conference, 519-522 (2020)

22. L.V. Osadchuk, O. I. Sebezhko, N.G. Shishin, O.S. Korotkevich, T.V. Konovalova, V.L. Petukhov, E.V. Fikhman, Bulletin of NSAU (Novosibirsk State Agrarian University) 2 (43), 52-61 (2017)

23. L.V. Osadchuk, M.A. Kleschev, O. I. Sebezhko, O.S. Korotkevich, V.L. Petukhov, Proceedings of the XXIII Congress of the Physiological Society, 2482-2484 (IP Pavlovawithinternationalparticipation, 2017)

24. O.I. Sebezhko, Chief zootechnician 7, 52-60 (2018)

25. O.I. Sebezhko, O.S. Korotkevich, D.M. Slobozhanin, E.Yu. Rosina, Enzymatic status of Kholmogr cattle cows, The role of agricultural science in sustainable development of rural areas. Collection of the IV All-Russian (national) scientific conference 97-99 (2019)

26. E.I. Tarasenko, D.A. Alexandrova, Biochemical status of cows with liver dysfunction, In the book: MNSC-2020. Biology. Materials of the 58th International Scientific Student Conference, 47 (2020)

27. E.I. Tarasenko, O. I. Sebezhko, A.V. Kovalev, I.N. Morozov, Variability of indicators of nitrogen metabolism of black-and-white cows in Kuzbass conditions, In the collection: The role of agricultural science in the sustainable development of rural areas. Collection of the V All-Russian (national) scientific conference, 256-259 (2020) 
28. N.I. Shishin, O. I. Sebezhko, Yu.I. Fedyaev, T.V. Skiba, T.V. Konovalova, K.N. Narozhnykh, Bulletin of NSAU (Novosibirsk State Agrarian University), 3 (44), 70-79 (2017) 